\title{
Use of psychoactive substances, body image and characteristics of personality traits in bodybuilders
}

\author{
Stosowanie środków psychoaktywnych, obraz własnego ciała \\ oraz charakterystyka cech osobowości u kulturystów
}

\section{Beata Pawłowska ${ }^{1} \mathrm{~A}, \mathrm{D}, \mathrm{E}, \mathrm{G}$, Zofia Zaręba ${ }^{2} \mathrm{~A}, \mathrm{~B}, \mathrm{D}, \mathrm{E}, \mathrm{F}$, Emilia Potembska ${ }^{3}{ }_{\mathrm{A}, \mathrm{C}, \mathrm{D}, \mathrm{E}}$}

$12^{\text {nd }}$ Department of Psychiatry and Psychiatric Rehabilitation of Medical University of Lublin, Poland

${ }^{2}$ Mazovian Centre of Occupational Medicine in Warsaw, Poland

${ }^{3}$ Department of Psychiatric Nursing of Medical University of Lublin, Poland

\section{Abstract}

The aim of the study was to determine the prevalence of psychoactive substances use as well as the characteristics of body image, self-image, narcissism and stress coping strategies in the group of male professional bodybuilders.

Material and method. The study comprised a group 30 male bodybuilders practising bodybuilding professionally for over 7 years and 30 men who did not practise any sport.

The following research methods were used in the study: Socio-demographic Questionnaire and Eating Disorders and Self-image Survey Questionnaire in Men designed by Pawłowska and Staniewicz, Coping with Stress Questionnaire by Janke, Erdmann, Boucsein, Narcissism Questionnaire by Deneke, Hilgenstock, Müller, Adjective Check List by Gough and Heilbrun in the authorised translation by Płużek.

Results. As compared to the control group, bodybuilders significantly more often use psychoactive agents and have a more negative body image and self-image and show intensified narcissism.

Conclusions: In comparison to the control group:

1. Significantly more bodybuilders use psychoactive agents: marijuana, amphetamine and ephedrine.

2. Bodybuilders are characterised by a significantly more negative body image related to the impression of having excessive fat tissue and not sufficient muscle tissue and intensified pursuing to obtain social acceptance.

3. Bodybuilders are characterised by a significantly more intensified need for dominance, aggression, competitiveness, breaking social rules, being rebellious, impulsive and confrontational.

4. Bodybuilders are characterised by significantly more intensified narcissistic traits.

5. Bodybuilders, while in a stressful situation, express compensatory conviction of having better than other people skills to cope with difficulties.

Keywords: bodybuilders, body image, personality, narcissism, coping with stress, drugs

\section{Streszczenie}

Celem pracy było określenie rozpowszechnienia stosowania środków psychoaktywnych oraz charakterystyka cech obrazu własnego ciała, obrazu siebie, narcyzmu i sposobów radzenia sobie ze stresem w grupie osób uprawiających zawodowo kulturystykę.

Materiał i metoda

Przebadano grupę 30 mężczyzn zawodowo uprawiających kulturystykę ponad 7 lat oraz 30 mężczyzn nieuprawiających zawodowo żadnego sportu.

W pracy zastosowano: Ankietę socjodemograficzną i Kwestionariusz do Badania Zaburzeń Odżywiania oraz Obrazu Własnego Ciała u Mężczyzn, autorstwa Pawłowskiej i Staniewicz, Kwestionariusz Radzenia Sobie ze Stresem Janke, Erdmann, Boucsein, Kwestionariusz Narcyzmu Deneke, Hilgenstock, Müller, Test Przymiotnikowy Gougha i Heilbruna.

Wyniki: Kulturyści porównaniu do grupy kontrolnej istotnie częściej stosują środki psychoaktywne, mają bardziej negatywny obraz własnego ciała i nasilony narcyzm.

Wnioski:

1. Istotnie więcej kulturystów niż mężczyzn uprawiających sport rekreacyjnie stosuje środki psychoaktywne.

2. Kulturystów charakteryzuje istotnie bardziej niż grupę kontrolną negatywny obraz własnego ciała oraz nasilone dążenie do uzyskania akceptacji społecznej.

3. Kulturyści w porównaniu do grupy kontrolnej charakteryzuje znacząco bardziej nasilona potrzeba dominacji, agresji, rywalizacji, łamania zasad społecznych, impulsywność, konfliktowość.

4. Kulturystów charakteryzują istotnie bardziej niż grupę kontrolną nasilony narcyzm.

5. Kulturyści istotnie częściej niż mężczyźni uprawiający sport rekreacyjnie w sytuacji stresu wyrażają kompensacyjne przekonanie o posiadaniu lepszych niż inni ludzie predyspozycji do poradzenia sobie z trudnościami.

Słowa kluczowe: kulturyści, obraz własnego ciała, osobowość, narcyzm, radzenie sobie ze stresem, narkotyki 


\section{Introduction}

Despite a prevailing opinion according to which there is a relationship between a positive body image and physical activity, the individuals practising sport are particularly predisposed to have a distorted self-image [1,2] In sportsmen the distortion of body image most frequently takes the form of muscle dysmorphia [3], which has been found not only in those practising bodybuilding, although in the majority of available research it concerns this group of subjects. Bodybuilding can be an amateur or professional sport discipline and it involves doing physical exercises with load, with the result of achieving hypertrophy of skeletal muscles and reduction of the fat tissue in order to expose muscles. Grieve [4] demonstrated the existence of dysmorphia symptoms in $5-10 \%$ of the examined male bodybuilders. This disorder occurs almost exclusively in men who being focused on too slim, not slim enough or muscular appearance, use special diets, exercise and/or do weight lifting in the excessive degree, which sometimes results in body damage. Some individuals try to develop their musculature using anabolic steroids and other illegal substances. In ICD-10 BDD (Body Dysmorphic Disorder) is included in hypochondriac disorders (F45.2).

While describing the origin of muscle dysmorphia Grieve [4] stresses the significance of such factors as: dissatisfaction with own body, sense of having a deformed body, practising sport disciplines which require both slim and muscular body, the influence of social media, internalisation of the beauty ideal for a given gender, low selfesteem, perfectionism, negative affect. Pope et al. [3] and Olivardia [5] while describing the risk factors of muscle dysmorphia address personality traits e.g. narcissism, perfectionism, low self-esteem and environmental factors: negative comments by family members and people around them regarding the body shape [6] and the impact of the ideal male body shape created by the media. Lantz et al. [7] point out that muscle dysmorphia originates from the initial growth in self-esteem and in body satisfaction following taking up training and resulting from muscle gain. In consequence the training individual gets more and more involved in trainings, on many occasions gradually giving up other aspects of everyday life, which leads to exercise addiction, strong desire for building athletic musculature, going on restrictive diets, abusing substances improving physical performance, including anabolic steroids and diet supplements. Angoorani et al. [8] address the issue of using amphetamine by bodybuilders in order to improve training effectiveness.

The distorted body image in women is related with a desire to be slim [9], whereas in case of men it is connected with the drive for building muscle mass and achieving an athletic build [9-11].
A significant relationship was demonstrated between dissatisfaction with one's musculature and low selfesteem, depression and lack of life satisfaction [12]. Low self-esteem is a predictive factor for distorted body image and body dissatisfaction, which leads in men to behaviours focused on muscle gain and/or intensification of distorted attitudes towards eating [13].

The researchers of the subject point out [14-16] that the main factors for developing muscle dysmorphia, which is so often described in the group of bodybuilders, include inter alia such personality traits as: narcissism, perfectionism, negative self-image, egocentrism, drive for competition. In case of bodybuilders, significantly higher narcissism intensity was found as compared to the non-training group and other groups of sportsmen [14]. According to Porcerelli and Sander [15], the sportsmen using anabolic steroids are most narcissistic. The men who work out in the gym on a regular basis experience a strong need for achievement and success, as compared to the men who do not exercise, they perceive themselves as better, more valuable, more exceptional, they want to attract other people's attention and show intensified perfectionism $[14,16]$. Keiller [16] characterises the males with high level of narcissism as individuals striving for power, dominance and control who, by such a grandiose attitude, try to compensate low selfesteem and internal emptiness. Keiller [16] thinks that they are afraid of intimacy and by hostile and aggressive attitude and low empathy level establishing authentic relationship by them becomes impossible. Due to the striving for improving selfesteem, which was observed in those practising power sports on a regular basis, including bodybuilding, the individuals characterised by low esteem more willingly get involved in bodybuilding exercise [7], but at the same more often use anabolic steroids [17]. Along with muscle building connected with using them, an increase in body satisfaction was demonstrated and after discontinuing steroid use - they experienced again lowered body satisfaction.

On the basis of the available literature the following research problems were formulated:

1) Do any differences occur, if any, between bodybuilders and males practising recreation sports as regards psychoactive agents?

2) Do any differences occur, if any, between bodybuilders and males practising recreation sports as regards body image?

3) Do any differences occur, if any, between bodybuilders and males practising recreation sports as regards psychological variables: self-image, narcissistic traits and stress coping strategies?

\section{Material and methods}

\section{Methods}

The following research methods were used in the study: Socio-demographic Questionnaire and Eating Disorders and Self-image Survey Questionnaire in Men (KBZOM II) designed 
by Pawłowska and Stankiewicz [18], Coping with Stress Questionnaire (KRS) by W. Janke, G. Erdmann and W. Boucsein [19], "N" Narcissism Questionnaire by Deneke, Hilgenstock, Müller [20], Adjective Check List by Gough and Heilbrun in the authorised translation by Płużek [21].

On the basis of the Socio-demographic Questionnaire the following parameters were determined: age, education level, place of residence, family structure of respondents, duration of practising a sports discipline, psychoactive agents used.

Eating Disorders and Self-image Survey Questionnaire in Men (KBZOM II) designed by Pawłowska and Staniewicz consists of 6-scale rating: excessive concentration on muscle mass, coping with negative emotions by binge eating, negative body image related to the sense of having excessive fat tissue and not sufficient muscle tissue, addiction to training and purging oneself and conviction that acceptance and friendship can be obtained exclusively thanks to having a muscular body. Cronbach's alpha reliability coefficients for individual scales oscillated from 0.93 to 0.72 [18].

Coping with Stress Questionnaire (KRS) by W. Janke, G. Erdmanni W. Boucsein consists of 19 scales evaluating various stress coping strategies. Cronbach's $\alpha$ for 19 ways of working out stress $\alpha=0.88$ [19].

"N" Narcissism Questionnaire by Deneke, Hilgenstock, Müller is composed of 18 scales evaluating the intensity of narcissistic traits. This Questionnaire examines additionally 4 dimensions of narcissism: "endangered I", "classical narcissistic I", "idealising I" and "hypochondriac I". The reliability coefficient for scales was from 0.52 to 0.96 [20].

On the basis of ACL, the self-image of respondents was evaluated. The correlation coefficients obtained in two examinations of the group of 56 men at 10 weeks' interval ranged from 0.54 to 0.85 [21].

\section{Subjects}

The above methods were used to examine a group consisting of 60 men (30 men practising bodybuilding professionally and 30 men who did not practise professionally any sport). The men who practised sport professionally on average had been doing sport for over 7 years $(\mathrm{SD}=4.32)$. The average age of the men was 23.9 years $(\mathrm{SD}=3.72)$.

The average age of the bodybuilders was 23.87 $(\mathrm{SD}=3.49$ ) years and in the control group $25.33(\mathrm{SD}=3.75)$ years. Twenty-six bodybuilders $(86.67 \%)$ and 2 men $(6.67 \%)$ from the control group lived in the urban areas. In the group of sportsmen 1 person (3.33\%) had primary level education, 24 men ( $80 \%$ ) had high school education and 5 respondents (16.67\%) - university education.

\section{Statistical analysis}

In order to compare the groups in terms of selected sociodemographic variables which are described on the nominal dichotomous scale, the nonparametric chi square test was used. In order to compare the two groups as regards personality variables the $t$-Student Test for independent groups was used.

\section{Results}

\section{Use of psychoactive agents by body builders}

In order to answer the question posed in the first research problem the chi-square test was used to compare the number of individuals using psychoactive substances in the group of bodybuilders and the control group (Table 1).

The obtained results show that significantly more bodybuilders, as compared to the males from the control group, use psychoactive agents such as marijuana, amphetamine and ephedrine. In the control group more than $23 \%$ of men report using smart drugs and $10 \%$ admitted to alcohol abuse. The compared groups did not differ in terms of respondents abusing alcohol and using smart drugs (Table 1).

\section{Body image in bodybuilders}

In order to answer the second research problem tStudent Test was used to compare the results obtained by the bodybuilders and the control group in KBZOM II scales (Table 2).

Table 1. Comparison of the number of bodybuilders and males from the control group as regards the use of psychoactive substances

\begin{tabular}{|c|c|c|c|c|c|c|}
\hline \multirow{2}{*}{ Use of anabolic steroids and psychoactive agents } & \multicolumn{2}{|c|}{ Bodybuilders } & \multicolumn{2}{|c|}{ Control Group } & \multirow[b]{2}{*}{ Chi sq. } & \multirow[b]{2}{*}{$\mathrm{p}$} \\
\hline & $\mathrm{N}$ & $\%$ & $\mathrm{~N}$ & $\%$ & & \\
\hline Anabolic steroids & 15 & 50.00 & 0 & 20.00 & 5.93 & 0.001 \\
\hline Marijuana & 13 & 43.33 & 6 & 20.00 & 3.77 & 0.050 \\
\hline Amphetamine & 7 & 23.33 & 0 & 0.00 & 7.92 & 0.005 \\
\hline Ephedrine & 8 & 26.67 & 0 & 0.00 & 9.23 & 0.002 \\
\hline Smart drugs & 3 & 10.00 & 0 & 0.00 & 3.16 & ns \\
\hline Alcohol & 7 & 23.33 & 9 & 30.00 & 0.34 & ns \\
\hline
\end{tabular}

$\mathrm{N}$-number of people; p-significance level 
Table 2. Comparison of average results obtained by the body builders and the control group in KBZOM II scales

\begin{tabular}{|l|c|c|c|c|c|c|}
\hline \multirow{2}{*}{ KBZOM II Scales } & \multicolumn{2}{c|}{ Bodybuilders } & \multicolumn{2}{c|}{ Control Group } & \multirow{2}{*}{$\mathrm{t}$} & $\mathrm{p}$ \\
\cline { 2 - 5 } & $\mathrm{M}$ & $\mathrm{SD}$ & $\mathrm{M}$ & $\mathrm{SD}$ & $\mathrm{t}$ & $\mathrm{p}$ \\
\hline Concentration on body mass & 1.22 & 0.79 & 0.13 & 0.25 & 7.23 & 0.001 \\
\hline Coping with emotions by binge eating & 0.50 & 0.76 & 0.25 & 0.46 & 1.55 & $\mathrm{~ns}$ \\
\hline Negative body image related to feeling of having excessive body mass & 0.62 & 0.62 & 0.23 & 0.29 & 3.09 & 0.004 \\
\hline Addiction to training & 1.75 & 0.72 & 0.41 & 0.40 & 8.89 & 0.001 \\
\hline Negative body image due to the sense of having a body not muscular enough & 1.04 & 0.67 & 0.65 & 0.76 & 2.13 & 0.040 \\
\hline Purging & 0.14 & 0.51 & 0.00 & 0.00 & 1.56 & $\mathrm{~ns}$ \\
\hline Social acceptance & 1.05 & 0.99 & 0.30 & 0.53 & 3.64 & 0.001 \\
\hline
\end{tabular}

M-mean; SD-standard deviation; t-Student Test

Table 3. Comparison of average results obtained by bodybuilders and the control group in ACL scales

\begin{tabular}{|c|c|c|c|c|c|c|}
\hline \multirow[b]{2}{*}{ ACL scales } & \multicolumn{2}{|c|}{ Bodybuilders } & \multicolumn{2}{|c|}{ Control Group } & \multirow[b]{2}{*}{$\mathrm{t}$} & \multirow[b]{2}{*}{$\mathrm{p}$} \\
\hline & $\mathrm{M}$ & SD & M & SD & & \\
\hline NCK (total number of adjectives checked) & 38.07 & 7.89 & 39.47 & 10.15 & -0.60 & ns \\
\hline FAV (favorable) & 43.50 & 6.98 & 45.47 & 7.27 & -1.07 & ns \\
\hline UFV (unfavorable) & 51.57 & 10.36 & 50.57 & 9.06 & 0.40 & ns \\
\hline COM (communality) & 36.97 & 7.20 & 38.20 & 8.39 & -0.61 & ns \\
\hline ACH (achievement) & 50.33 & 8.92 & 46.23 & 11.18 & 1.57 & ns \\
\hline DOM (dominance) & 51.97 & 8.27 & 46.27 & 8.57 & 2.62 & 0.011 \\
\hline END (endurance) & 49.60 & 7.49 & 50.33 & 11.46 & -0.29 & ns \\
\hline ORD (order) & 48.40 & 6.54 & 50.87 & 13.11 & -0.92 & ns \\
\hline INT (intraception) & 41.00 & 6.44 & 44.43 & 7.84 & -1.85 & ns \\
\hline NUR (nurturance) & 42.57 & 7.38 & 46.57 & 7.81 & -2.04 & 0.046 \\
\hline AFF (affiliation) & 47.60 & 8.73 & 47.83 & 9.41 & -0.10 & ns \\
\hline HET (heterosexuality) & 53.33 & 10.66 & 48.53 & 11.63 & 1.67 & ns \\
\hline EXH (exhibition) & 54.27 & 5.49 & 51.07 & 9.57 & 1.59 & ns \\
\hline AUT (autonomy) & 54.43 & 9.00 & 50.60 & 4.38 & 2.10 & 0.040 \\
\hline AGG (aggression) & 55.30 & 9.09 & 50.50 & 6.89 & 2.31 & 0.025 \\
\hline CHA (change) & 46.70 & 6.72 & 45.50 & 11.05 & 0.51 & ns \\
\hline SUC (succorance) & 45.60 & 8.50 & 49.63 & 8.12 & -1.88 & ns \\
\hline ABA (abasement) & 44.23 & 8.86 & 51.20 & 8.01 & -3.20 & 0.002 \\
\hline DEF (deference) & 44.43 & 8.48 & 48.20 & 5.12 & -2.08 & 0.043 \\
\hline CRS (counselling readiness) & 44.60 & 8.91 & 48.53 & 11.98 & -1.44 & ns \\
\hline SCN (self-control) & 46.20 & 6.59 & 49.63 & 8.64 & -1.73 & ns \\
\hline SCF (self-confidence) & 53.50 & 9.13 & 48.33 & 10.83 & 2.00 & 0.050 \\
\hline PAD (personal adjustment) & 43.63 & 8.21 & 46.60 & 6.72 & -1.53 & ns \\
\hline ISS (ideal self) & 52.60 & 9.43 & 51.77 & 8.91 & 0.35 & ns \\
\hline CPS (creative personality) & 50.70 & 6.14 & 49.63 & 7.83 & 0.59 & ns \\
\hline MLS (military leader) & 42.40 & 7.34 & 42.53 & 10.62 & -0.06 & ns \\
\hline MAS (masculinity) & 53.17 & 11.17 & 47.87 & 8.21 & 2.09 & 0.041 \\
\hline FEM (femininity) & 47.37 & 9.08 & 45.93 & 7.77 & 0.66 & ns \\
\hline $\mathrm{CP}$ (critical parent) & 54.30 & 8.43 & 49.30 & 8.49 & 2.29 & 0.026 \\
\hline NP (nurturing parent) & 46.23 & 6.73 & 49.50 & 7.57 & -1.77 & $\mathrm{~ns}$ \\
\hline A (adult) & 43.47 & 5.37 & 45.80 & 8.16 & -1.31 & ns \\
\hline FC (free child) & 54.00 & 6.97 & 51.20 & 12.05 & 1.10 & ns \\
\hline AC (adapted child) & 52.70 & 6.32 & 49.43 & 9.02 & 1.63 & ns \\
\hline
\end{tabular}

Abbreviations as in Table 2

The bodybuilders obtained statistically significantly higher results as compared to the men from the control group in KBZOM II scales: Concentration on body mass, Negative body image related to having excessive body mass, Addiction to training, Negative body image due to the sense of having a body not muscular enough and Social acceptance. The obtained results inform us that bodybuilders, as compared to the control group, are significantly more focused on building muscle mass, they more often measure chest cir- cumference, every day they look at their biceps in the mirror and believe that the bodybuilder silhouette is the ideal, most desirable silhouette, ensuring social acceptance, success in life and having friends. Compared to the men who do not practise any sport, bodybuilders significantly more often go on diets and have a more negative body image, which they view as "too fat" and also significantly more often feel compelled to exercise, are constantly preoccupied with training, continue training despite injuries, abandon meetings with 
family, friends if they prevent them from exercising, they feel anxiety and discomfort if they miss a training session and prefer training to meeting friends (table 2).

\section{Self-image in bodybuilders}

The results presented in Table 3 show the differences as regards self-image between male professional bodybuilders and males from the control group.

Compared to the control group, the bodybuilders obtained statistically significantly higher results in the scales: DOM, AUT, AGRR, SCF, MAS, CP, and significantly lower in ABA and DEF. The obtained results support a significantly intensified need in bodybuilders , as compared to the men practising sports only for recreation, for dominance, controlling others, imposing their opinion, stressing their independence, opposing authorities, breaking social rules, opposing limitations, intensified need for aggression, vindictiveness, fight, opposing others, hurting and punishing, criticising and humiliating others. As compared to the control group, bodybuilders are characterised by significantly higher reliance upon their abilities, aiming at making a good impression on others in order to be viewed upon as adamant, enterprising, self-confident, ambitious. Bodybuilders, compared to the men from the control group, are significantly more domineering, stubborn, impulsive, confrontational, stubbornly demanding what they think they deserve, more willing to compete with the others, aiming at defeating opponents and taking-up risks (table 3 ).

\section{Narcissism in bodybuilders}

The results presented in Table 4 show the differences as regards narcissistic traits between bodybuilders and males doing sports for recreation.
As compared to the control group, the bodybuilders obtained significantly higher results in the following Narcissism Questionnaire scales: NEK, GRS, GLB, NAW and HYA. The obtained results indicate that the male professional bodybuilders are characterised by significantly more intensified, as compared to the control group, lack of acceptance of their body, which is perceived as unattractive. This negative body image is compensated by bodybuilders by the sense of peculiar uniqueness resulting from confidence in their abilities, talents, intensified need to manipulate others in order to get recognition, acceptance, striving for being in the centre of attention. Moreover, as compared to the control group, the bodybuilders are characterised by a lower tolerance to frustration, criticism by other people and vindictiveness. Bodybuilders are characterised by excessive concentration on their health condition, which is manifested by intensified selfobservation, caring for health, concern for their body condition combined with fear of the potential illness (table 4).

\section{Coping with stress in bodybuilders}

Table 5 presents the results of the t-Student test, which was used to compare the stress coping strategies used by the body builders and the control group, included in the Coping with Stress Questionnaire.

As compared to the men practising sport for recreation, the bodybuilders significantly more often, while in a stressful situation, express the view that they are better predisposed than other people to cope with a difficult situation (table 5).

Table 4. Comparison of average results obtained by bodybuilders and control group in Narcissism Questionnaire (KN) scales

\begin{tabular}{|l|c|c|c|c|c|c|}
\hline \multirow{2}{*}{ KN scales } & \multicolumn{2}{|c|}{ Bodybuilders } & \multicolumn{2}{c|}{ Control Group } & \multirow{2}{*}{$\mathrm{t}$} & $\mathrm{p}$ \\
\cline { 2 - 4 } & $\mathrm{M}$ & $\mathrm{SD}$ & $\mathrm{M}$ & $\mathrm{SD}$ & $\mathrm{t}$ & $\mathrm{p}$ \\
\hline OHS (helplessness) & 1.85 & 0.53 & 1.80 & 0.63 & 0.28 & $\mathrm{~ns}$ \\
\hline AIV (loss of affect control) & 2.35 & 0.74 & 2.01 & 0.79 & 1.73 & $\mathrm{~ns}$ \\
\hline DRP (derealisation/depersonalisation) & 1.86 & 0.56 & 1.72 & 0.58 & 0.95 & $\mathrm{~ns}$ \\
\hline BAH (basic mood) & 3.16 & 0.63 & 3.19 & 0.89 & -0.17 & $\mathrm{~ns}$ \\
\hline KLS (self abasement) & 2.33 & 0.60 & 2.30 & 0.65 & 0.17 & $\mathrm{~ns}$ \\
\hline NEK (negative attitude to body) & 1.55 & 0.59 & 1.22 & 0.35 & 2.62 & 0.012 \\
\hline SOI (social isolation) & 2.75 & 0.61 & 2.49 & 0.95 & 1.26 & $\mathrm{~ns}$ \\
\hline ARR (archaic withdrawal) & 2.48 & 0.57 & 2.37 & 0.63 & 0.73 & $\mathrm{~ns}$ \\
\hline GRS (grandiose I) & 3.08 & 0.64 & 2.77 & 0.53 & 2.00 & 0.051 \\
\hline SIS (longing self I ideal) & 2.79 & 0.79 & 2.68 & 0.67 & 0.55 & $\mathrm{~ns}$ \\
\hline GLB (desire for glory and self - confirmation) & 2.67 & 0.66 & 2.33 & 0.68 & 1.98 & 0.052 \\
\hline NAW (narcissistic anger) & 2.58 & 0.55 & 2.26 & 0.58 & 2.14 & 0.037 \\
\hline AUI (self-sufficiency ideal) & 3.22 & 0.61 & 3.10 & 0.74 & 0.67 & $\mathrm{~ns}$ \\
\hline OBA (absement of others) & 2.96 & 0.53 & 2.68 & 0.70 & 1.71 & $\mathrm{~ns}$ \\
\hline WEI (price of the ideal) & 3.31 & 0.51 & 3.37 & 0.88 & -0.28 & $\mathrm{~ns}$ \\
\hline SYS (protection through symbiosis) & 3.36 & 0.56 & 3.34 & 0.73 & 0.08 & $\mathrm{~ns}$ \\
\hline HYA (hypochondriac binding of fear) & 2.26 & 0.83 & 1.87 & 0.60 & 2.08 & 0.042 \\
\hline NAK (narcissistic profit through illness) & 2.33 & 0.82 & 2.03 & 0.74 & 1.49 & $\mathrm{~ns}$ \\
\hline
\end{tabular}

Abbreviations as in Table 2 
Table 5. Comparison of average results obtained by the body builders and the control group in the Coping with Stress Questionnaire (KRS) scales

\begin{tabular}{|c|c|c|c|c|c|c|}
\hline \multirow{2}{*}{ KRS scales } & \multicolumn{2}{|c|}{ Bodybuilders } & \multicolumn{2}{|c|}{ Control Group } & \multirow[b]{2}{*}{$\mathrm{t}$} & \multirow[b]{2}{*}{$\mathrm{p}$} \\
\hline & $\mathrm{M}$ & SD & $\mathrm{M}$ & SD & & \\
\hline BAG (belittling) & 10.07 & 4.35 & 10.57 & 4.89 & -0.42 & ns \\
\hline PZI (comparison to others) & 10.77 & 5.36 & 8.37 & 4.24 & 1.92 & 0.05 \\
\hline OPW (defence against fault) & 8.80 & 4.11 & 8.50 & 3.88 & 0.29 & ns \\
\hline ODW (diverting attention) & 8.50 & 4.25 & 8.77 & 4.95 & -0.22 & ns \\
\hline ZSA (alternative satisfaction) & 8.27 & 5.13 & 6.40 & 4.58 & 1.49 & ns \\
\hline PSA (seeking self-affirmation) & 9.23 & 4.88 & 8.50 & 5.26 & 0.56 & ns \\
\hline PKPS (attempt to control the situation) & 11.80 & 4.83 & 11.87 & 5.57 & -0.05 & ns \\
\hline PKSR (attempt to control one's reactions) & 11.40 & 4.31 & 11.47 & 4.61 & -0.06 & ns \\
\hline PIS (positive self-instruction) & 10.53 & 4.99 & 10.53 & 4.80 & 0.00 & ns \\
\hline PSW (seeking social support) & 7.60 & 4.17 & 7.53 & 4.51 & 0.06 & ns \\
\hline TUN (avoiding tendency) & 9.60 & 3.83 & 10.10 & 4.54 & -0.46 & ns \\
\hline TUC (escaping tendency) & 6.20 & 3.63 & 7.17 & 4.68 & -0.89 & ns \\
\hline IZOL (isolation from other people) & 6.20 & 4.32 & 5.60 & 5.43 & 0.47 & ns \\
\hline DZWM (further preoccupation in thoughts) & 9.10 & 5.14 & 10.37 & 6.32 & -0.85 & ns \\
\hline RES (resignation) & 7.90 & 3.69 & 7.43 & 4.17 & 0.46 & ns \\
\hline UNS (self-pity) & 7.33 & 4.89 & 6.77 & 4.55 & 0.46 & ns \\
\hline OS (self-blaming) & 8.13 & 4.63 & 7.60 & 4.97 & 0.43 & ns \\
\hline AGR (aggression) & 6.93 & 4.61 & 5.77 & 4.27 & 1.02 & ns \\
\hline UZAL (dependence) & 3.13 & 3.72 & 2.40 & 2.88 & 0.85 & ns \\
\hline
\end{tabular}

Abbreviations as in Table 2

\section{Discussion of the results}

The results obtained in the study allowed us to provide an answer to research problems. It has been found that significantly more bodybuilders, as compared to the men practising sport for recreation, use psychoactive agents: marijuana, amphetamine and ephedrine. These findings correspond to the results obtained by Angoorani et al. [8], who showed the use of amphetamine by $13.3 \%$ of professional bodybuilders. In the opinion of Laties and Weiss [22] the use of psychoactive agents is observed as a new trend in bodybuilders and is aimed at improving their performance and training results.

The results of statistical analyses demonstrate that what makes bodybuilders from the control group different is significantly more intensified negative body image related to having - in their opinion- insufficient muscle tissue and excessive fat tissue, which involves intensified behaviours such as: frequent measuring chest circumference, looking at their biceps in the mirror on a daily basis, use of anabolic steroids, preoccupation with training, continuing training despite injuries, abandoning meetings with family, friends if they prevent them from exercising, anxiety and discomfort if they miss a training session. As compared to the control group, bodybuilders are characterised by significantly more intensified belief that it is only the bodybuilder silhouette that is ideal, most desirable, ensuring social acceptance, recognition, success in life and having friends.

The obtained results correspond to the opinion of researchers $[3,23]$, who point to the presence of intensified drive for developing musculature in the group of men practising bodybuilding and power sports. Mangweth et al. [24] demonstrate that professional bodybuilders show significantly more intensified dissatisfaction with their body and focussing on body mass as compared to the men who do not practise sport. Blouin and Goldfield [25] by comparing runners, martial artists and bodybuilders found that the bodybuilders obtained significantly higher results indicating the drive for putting on muscle mass accompanied at the same time by the drive for thinness, excessive concentration on body mass and using diets, perceiving their body as "too fat" and low self-esteem. Use of restrictive diets in order to get fat tissue reduction and to put on muscle mass in the form of bulk as well as training addiction were also observed in the research by Cella et al. [26]. Some researchers [27] point out that professional bodybuilders as compared to other athletes and those who did not practise any sport, have more distorted attitudes towards eating and negative body image.

The research results show significant differences between bodybuilders and males from the control group in terms of self-image characteristics, narcissism and use of stress-coping strategies. As compared to the control group, bodybuilders are characterised by an intensified need for dominance, aggression, breaking social rules and standards, criticising others, competition, being excessively confrontational, having tendency to manipulate others in order to attract attention, get acceptance, admiration, make good impression upon others. Bodybuilders want to be perceived by other people as self-confident, enterprising, ambitious individuals. Compared to the 
control group, bodybuilders are significantly more overbearing, stubborn, impulsive, stubbornly insisting on getting what, in their opinion, they deserve, more willingly competing with others, aiming at conquering rivals and taking up risk.

The obtained results point to significantly more intensified in bodybuilders, as compared to the control group, narcissistic characteristics: sense of particular uniqueness resulting from belief in one's capabilities, talents and aiming at being in the centre of attention. The above characteristics can be an attempt to compensate negative body image typical for body builders. Due to the fact that only muscular body can, according to this group of athletes, ensure acceptance, friendship, admiration of other people, they focus excessively on health care, show fear of their body condition and are afraid of potential illness, which could deprive them of the only source of satisfaction of their narcissistic striving and the need for acceptance and getting attention. Moreover, compared to the control group, bodybuilders are characterised by significantly lower tolerance to frustration, criticism from the others and vindictiveness.

Intensified narcissistic traits in the group of bodybuilders are accompanied by the most frequent methods of coping with stress used by them. Compared to the males who practise sport for recreation, bodybuilders, while in a stressful situation, significantly more often express grandiose conviction that they are better predisposed to cope with a difficult situation than other people.

Pawłowska and Stankiewicz [14] found a significantly higher narcissism intensity in the group of bodybuilders than in the non-training group and other groups of athletes. Porcerelli and Sander [15] point out that significantly higher narcissism intensity was found to be the athletes using anabolic steroids. Keiller [16] characterises the males with high narcissism level as the individuals striving for power, dominance and control of others, hostile, aggressive towards other people, with low empathy level. They conceal low self-esteem and internal emptiness behind a grandiose attitude. According Szabo and Griffiths [28] intensive training can be viewed upon as a stress coping strategy or mood elevation strategy. Similar results were obtained by Faganel and Tusak [29], who demonstrated that Slovenian bodybuilders were convinced about having higher moral standards and being guided by better values than other people; they viewed themselves as more cultured, better socially adapted, capable of self-control, quiet, making a positive first impression upon others. The bigger muscles the respondents had, the more positive characteristics they ascribed to themselves [29]. According to Faganel and Tusak [29] the following characteristics: high self-esteem, selfconfidence, striving for dominance, independence, convic- tion of being more valuable, desire to impress the others but also a lack of criticism, looking for confirmation from the others can be observed in body builders; they make them different from individual practising other sport disciplines and from those non-training any sport on a professional basis. Similarly, Koca and Asci [30] point to such characteristics shown by bodybuilders as: strong competitiveness, assertiveness, striving for independence and striving for taking risks.

The research carried out by the authors of this paper presents the problem of using psychoactive substances by bodybuilders and also point to some personality traits that can be risk factors to use these substances by this group of athletes. The results presented have some limitations, one of them being a small sample size. The number of individuals reporting the use of psychoactive substances can be understated despite the fact that respondents were assured about the anonymity of results.

\section{Conclusions}

On the basis of the results obtained in the study, the following conclusions were formulated:

Compared to the control group:

1) significantly a higher number of bodybuilders use psychoactive agents: marijuana, amphetamine and ephedrine,

2) bodybuilders are characterised by a significantly more negative body image related to the impression of having excessive fat tissue and not sufficient muscle tissue and intensified pursuing to obtain social acceptance,

3) bodybuilders are characterised by a significantly more intensified need for dominance, aggression, competitiveness, breaking social rules, being rebellious, impulsive and confrontational,

4) bodybuilders are characterised by significantly more intensified narcissistic characteristics,

5) bodybuilders, while in a stressful situation, express compensatory conviction of having better than other people skills to cope with difficulties.

\section{References:}

1. Engel SG, Johnson C, Powers PS, Crosby RD, Wonderlich SA, Wittrock DA, et al. Predictors of disordered eating in sample of elite Division I college athletes. Eating Behaviors, 2003;4(4):333-43.

2. Beals KA. Disordered eating among athletes: A comprehensive guide for health professionals. Human Kinetics; 2004.

3. Pope HG, Phillips KA, Olivardia R. The Adonis Complex: The Secret Crisis of Male Body Obsession. New York, NY: The Free Press; 2000.

4. Grieve FG. A conceptual model of factors contributing to the development of muscle dysmorphia. Eat Disord. 2007;15(1):63-80.

5. Olivardia R. Mirror, mirror on the wall, who's the largest of them all? The features and phenomenology of muscle dysmorphia. Harv Rev Psychiatry. 2001;9(5),254-9. 
6. Cafri G, Yamamija Y, Brannick M, Thompson JK. The influence of sociocultural factors on body image: A meta-analysis. Clin Psychol Sc Pract. 2005;12(4):421-33.

7. Lantz CD, Rhea DJ, Mayhew JL. The drive for size: a psycho behavioural model of muscle dysmorphia. Int Sports J. 2001;5(1):71-86.

8. Angoorani H, Narenjiha H, Tayyebi B, Ghassabian A, Ahmadi G, Assari S. Amphetamine use and its associated factors in body builders: a study from Tehran, Iran. Arch Med Sci. 2012; 8(2):362-7.

9. Ricciardelli LA, McCabe MP. Self-esteem and negative affect as moderators of sociocultural influences on body dissatisfaction, strategies to decrease weight, and strategies to increase muscles among adolescent boys and girls. Sex Roles. 2001;44(3-4):189-207.

10. Smolak L, Stein JA. The relationship of drive for muscularity to sociocultural factors, self-esteem, physical attributes gender role, and social comparison in middle school boys. Body Image. 2006;3(2):121-9.

11. Bergeron D, Tylka TL. Support for the uniqueness of body dissatisfaction from drive for muscularity. Body Image. 2007;4(3):288-95.

12. Cafri G, Strauss J, Thompson JK. Male body image: Satisfaction and its relationship to well-being using the somatomorphic matrix. Intl J Mens Health. 2002;1(2):215-31.

13. Cafri G, Thompson JK, Ricciardelli L, McCabe M, Smolak L, Yesalis C. Pursuit of the muscular ideal: Physical and psychological consequences and putative risk factors. Clin Psychol Rev. 2005;25(2):215-39.

14. Pawłowska B, Stankiewicz Z. The narcissistic features and eating disorders in male bodybuilders. Curr Probl Psychiatry. 2010;11(4):384-8.

15. Porcerelli JH, Sander BA. Narcissism and empathy in steroid users. Am J Psychiatry. 1995;152(11):1672-4.

16. Keiller S. Male narcissism and attitudes toward heterosexual women and men, lesbian women and gay men: Hostility toward heterosexual women most of all. Sex Roles. 2010;63(7-8):530-41.

17. Irving LM, Wall M, Neumark-Sztainer D, Story M. Steroid use among adolescents: Findings from project EAT. J Adolesc Health. 2002;30(4):243-52.

18. Pawłowska B, Stankiewicz Z, Potembska E. [Psychometric properties of Eating Disorders and Self-image Survey Questionnaire in Men (KBZOM II)]. Curr Probl Psychiatry. 2012;13(1):18-24. Polish.

19. Januszewska E. [Coping with Stress Questionnaire. Diagnostic value and test results involving adolescents]. In: Oleś P, editor. [Selected issues from clinical psychology and personality. Diagnostic methods in research involving children and adolescents]. Lublin: Towarzystwo Naukowe KUL; 2005. p. 91-124. Polish.

20. Januszewski A. [Narcissism Questionnaire. Diagnostic value in the light of results of research involving Polish adolescents]. In: Oleś $\mathrm{P}$, editor. [Selected issues from clinical psychology and personality psychology. Diagnostic methods in research involving children and adolescents]. Lublin: Towarzystwo Naukowe KUL; 2005. p. 153-196. Polish.
21. Juros A, Oleś P. [Factor and cluster structure of ACL by H.G. Gough and A.B.Heilbrun] In: Brzeziński J, Hornowska E, editors. [From psychometric issues of psychological diagnostics]. Poznań: Wydawnictwo Naukowe Uniwersytetu im. A. Mickiewicza; 1993. p. 171-201. Polish.

22. Laties VG, Weiss B. The amphetamine margin in sports. Fed Proc. 1981;40:2689-92.

23. Kyrejto JW, Mosewich AD, Kowalski KC, Mack DE, Crocker PRE. Men's and women's drive for muscularity: Gender differences and cognitive and behavioural correlates. Int J Sport Exerc Psychol. 2008;6(1):69-84.

24. Mangweth B, Pope HR Jr, Kemmler G, Hausmann A, De Col C, Kreuner B, et al. Body image and psychopathology in male bodybuilders. Psychother Psychosomatics. 2001;70(1):38-43.

25. Blouin AG, Goldfield GS. Body image and steroid use in male bodybuilders. Int J Eat Disord. 1995;18(2):159-65.

26. Cella S, Iannaccone M, Cotrufo P. Muscule dysmorphia: A comparison between competitive bodybuilders and fitness practitioners. J Nutr Ther. 2012;1(1):12-8.

27. Rubinstein G. Macho man: Narcissism, homophobia, agency, communion, and authoritarianism- a competitive study among Israeli bodybuilders and a control group. Psychol Men Masc. 2003;4(2):100-10.

28. Szabo A, Griffiths MD. Exercise addiction in British sport science students. Int J Ment Health Addict. 2007;5(1):25-8.

29. Faganel M, Tusak M. Psychological profile of Slovene bodybuilders. Rev Psychol. 2005;12(1):55-61.

30. Koca C, Asci FH. Gender role orientation in Turkish female athletes. Women Sport Physical Activ J. 2005;14(1):86-94.

\section{Correspondence address}

Beata Pawłowska

Department of Psychiatry and Psychiatric Rehabilitation of Medical University of Lublin, Poland 20-439 Lublin, ul. Głuska 1 Phone: 817440967

e-mail: pawlowskabeata@tlen.pl

Otrzymano: 01.12.2015

Zrecenzowano: 01.01.2016, 31.01.2016

Przyjęto do druku: 08.02.2016 